\title{
Faktor Fundamental dan Abnormal Return Perusahaan Makanan dan Minuman
}

\section{Warsono $^{1}$}

${ }^{1}$ Universitas Pancasila, Jl. Raya Lenteng Agung, Jagakarsa, Jakarta Selatan 12640

\section{N F O A R T I K E L \\ JEL Classification: \\ G14 \\ F62}

\section{Keywords:}

operating cash flo, price earnings ratio, return on equity, debt to equity ratio, size, abnormal stock return.
A $B$ S T $R$ R A C $T$

Financial statement is one of source information that is needed for the economic decision maker, especially for stock exchange performers. It reflects company's performance during the period. The other one is statement of cash flow from operating activities that reflect their performance on their daily activities. This research aim to get empirical evidence on the influence of financial performance that are represented by operating cash flow, price earnings ratio, return on equity, debt to equity ratio, and size to the abnormal stock return. This research take 12 samples of food and beverages companies which are listed in Indonesia Stock Exchange from 2011-2015. The method used in the research by using multiple linear regression analysis. This study concludes that operating cash flow have no influence to the abnormal stock return. Price earnings ratio, return on equity, debt to equity ratio, and size significantly effect toward abnormal return. Size has a dominant influence to the abnormal stock return. It means that size is the best representation of independent variables to appraise that abnormal stock return on food and beverages company.

\section{A B S T R A K}

laporan keuangan merupakan salah satu sumber informasi yang diperlukan untuk pengambilan keputusan ekonomi, terutama untuk investor di bursa saham. Hal ini mencerminkan kinerja perusahaan selama periode tersebut. Informasi lain yang penting adalah laporan arus kas dari aktivitas operasi yang mencerminkan kinerja mereka pada kegiatan sehari-hari mereka. Penelitian ini bertujuan untuk mendapatkan bukti empiris tentang pengaruh kinerja keuangan yang diwakili oleh arus kas operasi, Price Earning Ratio, Return on Equity, Rasio hutang terhadap ekuitas, dan ukuran untuk return saham yang abnormal. Penelitian ini mengambil 12 sampel perusahaan makanan dan minuman yang terdaftar di Bursa Efek Indonesia dari tahun 2011-2015. Metode yang digunakan dalam penelitian ini dengan menggunakan analisis regresi linier berganda. Penelitian ini menyimpulkan bahwa arus kas operasi tidak memiliki pengaruh terhadap return saham yang abnormal. Price Earning Ratio, Return on Equity, Debt to Equity ratio, dan ukuran secara signifikan mempengaruhi terhadap return abnormal. Ukuran perusahaan memiliki pengaruh dominan terhadap return saham yang abnormal. Ini berarti bahwa ukuran adalah representasi terbaik dari variabel independen untuk menilai bahwa return saham abnormal pada makanan dan minuman perusahaan. 


\section{Pendahuluan}

Berinvestasi di pasar modal dalam bentuk sekuritas saham memiliki potensi perolehan return yang lebih besar dan dalam waktu yang lebih singkat dari pada berinvestasi pada aset riil. Akan tetapi perlu diketahui investor, return saham ditandai dengan variabilitas atau fluktuasi harga yang membentuk risiko. Keputusan investasi bagi para investor mengandung risiko dan ketidakpastian. Pengetahuan tentang risiko merupakan suatu hal yang penting untuk dimiliki setiap investor maupun calon investor. Sebelum mengambil keputusan investasi, investor yang rasional harus mempertimbangkan dua hal yaitu pendapatan yang diharapkan dan risiko.

Investasi pada saham bertujuan untuk mencari keuntungan berupa return baik jangka pendek maupun jangka panjang. Bagi investor di pasar perdana keuntungan jangka pendek berupa initial return sudah dapat diketahui pada penutupan hari pertama saham tersebut diperdagangkan di bursa efek. Keuntungan tersebut diperoleh dari selisih antara harga penutupan perdagangan hari pertama dan harga penawaran perdana pada waktu Initial Public Offering (IPO). Adapun keuntungan jangka panjang dalam bentuk abnormal return, diperoleh dari return realisasi (realized return) dikurangi dengan return ekspektasi (expected return). Jika harga saham naik, maka keruntungan return yang dimiliki investor akan meningkat. Kenaikan harga saham dan permintaan yang tinggi merupakan daya tarik perusahaan untuk menerbitkan saham sebagai alternatif dalam penyediaan dana. Informasi perkembangan harga saham merupakan informasi yang penting bagi investor atau calon investor yang akan berinvestasi pada pasar modal.

Faktor yang mempengaruhi harga saham dan return saham individual tidak hanya berasal dari faktor internal perusahaan, tetapi juga faktor eksternal perusahaan seperti informasi makro, politik, keamanan, nilai tukar rupiah terhadap dolar dan kondisi pasar; namun demikian faktor internal masih berpengaruh dominan terhadap harga saham dan return saham individual. Perubahan harga saham individual, tergambar pada pergerakan indeks utama di pasar Indonesia yang disebut indeks harga saham gabungan (IHSG). Agar dapat memperhitungkan potensi perolehan return, investor memerlukan informasi yang akurat yang dapat digunakan sebagai bahan analisis saham baik faktor fundamental maupun faktor teknikal. Kinerja fundamental dipengaruhi oleh kemampuan perusahaan menghasilkan laba dan kemampuan perusahaan memenuhi kuwajibannya. Faktor teknikal dipengaruhi oleh perubahan harga historik termasuk indeks pasar pada saat saham tersebut diperdagangkan. Salah satu informasi yang diperlukan investor adalah informasi laporan keuangan tahunan khususnya neraca dan laporan laba rugi perusahaan.

Analisis fundamental dapat membantu memperediksi pengembalian saham di masa yang akan datang dan untuk menjelaskan momentum dalam harga-harga saham (Nguyen 2004 dalam Abidin, 2009). Beberapa penelitian mengenai kegunaan informasi akuntansi (laporan keuangan) dalam hubungannya dengan return saham di Bursa Efek Indonesia, telah banyak dilakukan, antara lain oleh Michel Suhardi (2005) melakukan studi empiris terhadap dua faktor yang mempengaruhi return saham. Hasil penelitian menemukan rasio hutang dan tingkat risiko tidak memberikan pengaruh yang signifikan terhadap return saham. Ullupui (2009) menganalisis pengaruh rasio likuiditas, leverage, aktivitas dan profiabilitas terhadap return saham menemukan variabel current ratio (CR), return on asset (ROA) berpengaruh positif dan signifikan terhadap return saham. Sedangkan variabel debt equity ratio (DER) menunjukkan hasil yang positif dan signifikan terhadap return saham dan variabel total asset turn over (TATO) menunjukkan hasil yang negative dan tidak signifikan terhadap return saham.

Sivaprasad dan Muradoglu (2010), menguji secara empirik hubungan antara financial leverage (DAR dan DER) dan expected return saham pada industri utilities dan indudtri minyak dan gas di pasar modal London. Mereka menemukan hubungan positif signifikan antara financial leverage dan expected return saham pada industri utilities. Namun pada saham-saham 
industri minyak dan gas mereka temukan adanya hubungan negatif antara financial leverage dan expected return. Gomes dan Schmid (2008) Menguji hubungan leverage (debt to asset dan debt to equity ratio) dengan stock expected return dalam kondisi pasar modal yang sedang tidak sempurna. Mereka menyatakan bahwa dalam kondisi ini investasi akan sangat berkorelasi dengan leverage, sehingga hubungan antara financial leverage dan expected return menjadi sangat rumit.

Pendapat serupa dikemukakan Nainggolan (2004) dalam penelitiannya menggunakan variabel earning per share (EPS), debt equity ratio (DER), price earning ratio (PER), return on investmen (ROI) dan return on equiry (ROE) berpengaruh terhadap harga saham perusahaan sektor properti, Sunarto (2001) meneliti pengaruh kinerja fundamental terhadap return saham perusahaan manufaktur periode 1998/1999 dan 1999/2000. Penelitian yang dilakukan menemukan bahwa ratio profitabilitas Return on Asset (ROA), Return on Asset (ROE) dan leverage berpengaruh signifikan terhadap return saham. Dari ketiga variabel, Return on Asset (ROA), Return on Asset (ROE) berpengaruh paling konsisten dan variabel leverage tidak konsisten berpengaruh terhadap return saham

Lain halnya dengan penelitian yang dilakukan oleh Korteweg (2004), Dimotrov dan Jain (2005) dan Penman (2007) menemukan bahwa indikasi hubungan antara financial leverage dan return saham beragam pada berbagai industri yang berbeda. Argumentasinya adalah bahwa pada industri-industri yang berbasis pada natural resources lebih sensitif terhadap sumber pendanaan berupa hutang. Semakin besarnya pendanaan berupa hutang akan semakin besar pula financial risk dan kondisi ini berpotensi terhadap semakin menurunnya return.

Sasongko dan Wulandari (2006) yang meneliti tentang pengaruh EVA dan rasio-rasio profitabilitas terhadap harga saham, siperoleh kesimpulan bahwa secara parsial menunjukkan bahwa return on asset, return on equity, return on sale, basic earning power, dan economic value added tidak berpengaruh terhadap harga saham.
Penelitian yang hampir serupa dilakukan oleh Anastasia, menganalisis faktor fundamental dan risiko sistematik terhadap harga saham Hasil analisis menunjukkan bahwa secara parsial hanya faktor fundamental book value (BV) yang mempengaruhi harga saham sedangkan faktor fundamental lainnya (ROA, ROE, Payout ratio) tidak berpengaruh terhadap harga saham.

Selanjutnya Abidin (2009) melakukan penelitian pngaruh faktor fundamental terhadap harga saham. Dengan menggunakan variabel return on asset (ROA), return on equiry (ROE), price earning ratio (PER), debt equity ratio (DER), required rate of return, earning per share $(E P S)$, book value $(B V)$, return on investmen (ROI), operating profit margin (OPM) dan beta. Hasil penelitiannya menuunjukkan bahwa return on asset (ROA), return on equiry (ROE), price earning ratio (PER), debt equity ratio (DER) dan required rate of return memilik berpengaruh yang rendah terhadap harga saham. Sedangkan variabel earning per share (EPS), book value (BV), return on investmen (ROI), operating profit margin (OPM) dan beta secara simultan berpengaruh signifikan terhadap harga saham.

Informasi laporan keuangan yang berpengaruh terhadap abnormal return saham antara lain dikemukakan oleh Suryaningrum dan Hartono (2000) yang meneliti abnormal return dengan strategi analisis fundamental, menyimpulkan sinyal persediaan, pengeluaran modal, margin kotor berhubungan secara positif dengan abnormal return. Sedangkan sinyal piutang dagang, penjualan dan pajak efektif berhubungan secara negatif dengan abnormal return.

Hermansyah dan Ariesanti (2006), meneliti pengaruh laba bersih terhadap harga saham. Hasil penelitian mebuktikan bahwa laba bersih berpengauh secara signifikan lebih kecil dibandingkan dengan faktor suku bunga, IHSG dan news and rumors. Lain halnya penelitian yang dilakukan oleh Kusuma dan Rahardjo (2004), yang meneliti kandungan informasi dari laba, modal kerja dan arus kas operasi pada perusahaan manufaktur. Hasil penelitiannya menemukan perubahan laba memiliki kandungan informasi 
tambahan dalam memprediksi return saham, perubahan modal kerja memiliki kandungan informasi tambahan dalam memprediksi return saham; yang berarti tinggi rendahnya return saham tergantung tinggi rendahnya modal kerja. Sedangkan informasi arus kas operasi memiliki kandungan informasi tambahan dalam memprediksi return saham; yang berarti tinggi rendahnya return saham tergantung tinggi rendahnya arus kas operasi. Berbeda dengan penelitian yang dilakukan oleh Wahyuni (2002), menemukan bahwa informasi arus kas pada kondisi baik dan buruk, tidak bepengaruh secara signifikan terhadap return saham.

Penelitian mengenai pengaruh price earning ratio (PER) terhadap return saham, antara lain diteliti oleh Aydogan dan Gursoy (2000), menguji secara empirik Price Earning Ratio (PER) dan Price to Book Value (PBV) sebagai prediktor stock return di pasar modal negara berkembang. Mereka menemukan bahwa kedua rasio ini memiliki kemampuan signifikan dlam menjelaskan expected return saham sepanjang waktu. Trevino dan Robertson (2002) meneliti Price Earning Ratio saat ini dan return pasar saham rata-rata pada Nasdaq Stock Exchane. Hasil penelitian menunjukkan $\mathrm{P} / \mathrm{E}$ ratio memiliki korelasi kecil dengan return rata-rata jangka pendek (kurang dari tiga tahun) dan return jangka panjang (lebih darilima tahun) lebih rendah setelah periode $\mathrm{P} / \mathrm{E}$ ratio yang tinggi, akan tetapi masih lebih tinggi dari pada investasi pada obligasi. Aga dan Kocaman (2006), meneliti hubungan antara inflasi, indeks industrial, Price Earning Ratio (PER) dan return saham di pasar modal Istambul. Mereka menemukan bahwa inflasi dan indeks industrial tidak dapat memprediksi return saham, tetapi price eraning ratio (PER) mampu memprediksi return saham.

Huang, Tsai dan Chen (2007) dalam penelitiannya menemukan bahwa $\mathrm{P} / \mathrm{E}$ ratio dalam komponen fundamental memberikan performen positif dalam portofolio saham. Penelitian serupa dilakukan oleh Hadianto (2008) yang meneliti tentang pengaruh Earning Per Share (EPS) dan price earning ratio (PER) terhadap harga saham; menemukan Earning Per Share (EPS) dan Price
Earning ratio (PER) baik secara parsial maupun secara simultan berpengaruh positif terhadap harga saham.

Selain faktor fundamental di atas, ukuran perusahaan (Size) memberikan dukungan yang kuat terhadap return saham. Senthilkumar (2009), dalam penelitiannya menemukan bahwa perusahaan kecil menciptakan return rata-rata yang tinggi dibandingkan dengan perusahaan besar di India. Sedangkan book value memberikan dukungan yang kuat terhadap return saham. Berbeda dengan penelitian oleh Kartika (2007) yang meneliti pengaruh size terhadap risiko sistimatik (beta). Dalam penelitiannya menemukan bahwa semakin besar ukuran perusahaan risiko sistematik atau beta semakin kecil. Artinya bahwa semakin besar ukuran perusahaan semakin besar return saham karena risiko semakin kecil.

Uraian di atas menunjukkan bahwa hasil penelitian mengenai pengaruh faktor fundamental terhadap return saham masih variatif dan penelitian yang telah dilakukan sebagian besar hanya memperhitungkan expected return tanpa memperhitungkan actual returnnya. Melihat aktivitas, laba dan leverage perusahaan berpengaruh terhadap return saham masih menjadi perhatian penting para investor, maka penelitian ini ingin menganalisis kembali temuan penelitian sebelumnya dari sudut fundamental perusahaan, yaitu, arus kas operasi dan rasio keuangan terdapat dalam laba, terutama, price earning ratio (PER), Return on Equity (ROE) dan debt equity ratio serta size pengaruhnya terhadap abnormal return saham.

Operating Cash Flow merupakan aliran kas yang berasal dari kegiatan operasi utama perusahaan. Jumlah arus kas tersebut dapat digunakan sebagai tolok ukur untuk menilai perusahaan dalam menghasilkan kas yang cukup untuk melunasi pinjaman, membayar deviden dan melakukan investasi baru tanpa mengandalkan sumber pendapatan dan pendanaan. Informasi Operating Cash Flow dapat digunakan untuk memprediksi return saham, pada hal pada saat berinvestasi investor akan selalu mensyaratkan dan mengharapkan return tertentu. Untuk itu 
investor perlu menganalisis kondisi keuangan perusahaan untuk mengetahui kemampuan dalam menghasilkan laba per lembar saham atau earning per share. Dengan demikian investor juga akan dapat menganalisis Price Earning Ratio hubungannya dengan abnormal return saham

Price Earning Ratio(PER) mencerminkan beberapa besar uang yang berani dibayar oleh investor untuk setiap lembar saham. Price Earning Ratio biasanya terkait dengan tahap pertumbuhan perusahaan, sehingga perusahaan-perusahaan yang sedang berada dalam tahap pertumbuhan biasanya memiliki nilai. Price Earning Ratio yang lebih tinggi. Rasio ini sebagai alat ukur untuk menilai tingkat pertumbuhan perusahaan. Semakin meningkatnya Price Earning Ratio memceriminkan pertumbuhan perusahaan. Hal ini menunjukkan kinerja perusahaan akan semakin meningkat. Meningkatnya kinerja perusahaan memberikan respon positif bagi investor, yang mengakibatkan meningkatnya harga saham. Semakin meningkatnya harga saham dengan sendirinya meningkatkan abnormal return saham. Hal ini berarti bahwa jika Price Earning Ratio meningkat, abnormal return saham juga akan meningkat.

Indikator lainnya dalam untuk mengetahui profitabilitas pengaruhnya terhadap abnormal return saham adalah Return On Equity (ROE). Jika Return On Equity tinggi, investor dapat melihat pertumbuhan profitablitas perusahaan semakin meningkat, yang berarti bahwa kinerja perusahaan semakin meningkat. Kinerja perusahaan yang meningkat akan direspon positif oleh investor, sehingga harga saham akan semakin meningkat. Dengan meningkatnya Return On Equity maka abnormal return saham diprediksikan meningkat.

Analisis fundamental selain laba, indikator hutang dan ukuran perusahaan (size) perlu menjadi perhatian dalam memprediksi abnormal return saham. Debt to Equity Ratio (DER) menunjukkan kemampuan perusahaan dalam membayar hutang dengan equity yang dimilikinya. Alat analisis ini digunakan untuk mengetahui besarnya perusahaan memiliki financial risk, debt to equity ratio yang semakin besar akan mengakibatkan risiko finansial perusahaan semakin tinggi. Dengan penggunaan hutang yang semakin besar akan mengakibatkan semakin tinggi risiko untuk tidak mampu membayar hutang. Investor pada dasarnya menghindarkan diri dari resiko. Meningkatnya Debt to Equity Ratio berarti akan meningkatkan resiko berinvestasi, dengan demikian investor merespon negatif terhadap kinerja perusahaan. Rendahnya kinerja perusahaan berakibat harga saham semakin menurun. Menurunnya harga saham mengakibatkan abnormal return saham yang semakin menurun. Dengan meningkatnya Debt to Equity Ratio maka abnormal return saham diprediksikan menurun.

Sedangkan total aset sebagai ukuran perusahaan (Size) yang merupakan seluruh aktiva yang dimiliki perusahaan, terdiri atas akiva lancar dan aktiva tetap menunjukkan efisiensi perusahaan dan prospek dimasa yang akan datang. Total asset yang besar akan meningkatkan efisiensi dari perusahaan dan memberikan prospek pertumbuhan yang semakin besar. Prospek pertumbuhan yang meningkat investor memberikan respon positif terhadap kinerja perusahaan yang berakibat harga saham semakin meningkat. Meningkatnya harga saham berakibat meningkatnya abnormal return saham. Dengan meningkatnya Size maka abnormal return saham diprediksikan meningkat.

Tujuan penelitian ini adalah untuk memberikan temuan empiris tentang pengaruh variable akuntansi, khususnya yang berkaitan dengan arus kas dan rasio keuangan terdapat dalam laba, leverage dan ukuran perusahaan pada tingkat individual terhadap abnormal return saham yang masuk kategori industri makanan dan minuman yang terdaftar di Bursa Efek Indonesia (BEI) sejak tahun 2011-2015.

\section{Telaah Teori dan Pengembangan Hipotesis}

Abnormal return (exes return) merupakan pengembalian investasi adalah kelebihan dari return yang sesungguhnya terjadi pada return normal. Return normal merupakan return expektasi (return yang diharapkan investor). 
Sedangkan return sesungguhnya merupakan return yang terjadi pada waktu ke-t, yang merupakan selisih harga sekarang relatif terhadap harga sebelumnya. Dengan demikian arti sesunguhnya dari return tidak normal (abnormal return) adalah selisih antara return sesunggunya terjadi dengan return expektasi (Husnan ,2003).

Return realisasi (sesungguhnya) yang sering disebut juga actual return (Rit) dapat dihitung dengan rumus sebagai berikut :

Rit $=\frac{\text { Pt - Pt-1 + D }}{\text { Pt-1 }}$

dijelaskan sebagai berikut :

$$
\begin{aligned}
& \text { Rit }=\text { Return saham realisasi } \\
& \mathrm{Pt}=\text { Harga saham pada periode } \mathrm{t} \\
& \mathrm{Pt}-1=\text { Harga saham pada periode } \mathrm{t}-1 \\
& \mathrm{D}=\text { Dividen }
\end{aligned}
$$

Sedangkan expected return dihitung dengan menggunakan metode market adjusted model, model ini return sekuritas yang diestimasi sama dengan return indeks pasarnya. Sehingga expected teturn dihitung dengan rumus: (Jogiyanto,2003)

$$
\begin{array}{ll}
\mathrm{E}(\text { Rit })= & \alpha+\beta . \mathrm{E}(\mathrm{Rmt}) \\
\mathrm{E}(\text { Rit })= & \text { Expected Return } \\
\alpha= & \text { Intersep saham } \\
\beta & \text { Koefisien slope yang merupakan } \\
& \text { beta saham } \\
\mathrm{E}(\mathrm{Rmt})= & \begin{array}{l}
\text { Return ekspektasi pasar pada } \\
\text { periode ke t yang nilainya }=\mathrm{Rm}
\end{array}
\end{array}
$$

Sedangkan return pasar $(\mathrm{Rm})$ berdasarkan indeks pasar IHSG, yang dapat dihitung dengan rumus sebagai berikut.

$$
\mathrm{Rm}=\frac{\mathrm{IHSG}_{\mathrm{t}}-\mathrm{IHSG}_{\mathrm{t}-1}}{\mathrm{IHSGt}-1}
$$

dijelaskan sebagai berikut :

$$
\begin{aligned}
\mathrm{Rm}= & \text { Return pasar } \\
\mathrm{IHSGt}= & \text { Indeks harga saham gabungan } \\
& \text { pada periode } \mathrm{t} \\
\mathrm{IHSGt}-1= & \text { Indeks harga saham gabungan } \\
& \text { pada periode } \mathrm{t}-1
\end{aligned}
$$

IHSGt merupakan indeks harga saham gabungan pada periode saat ini dan IHSG(t-1) merupakan indeks harga saham gabungan periode sebelumnya.

Pengukuran abnormal return dalam penelitian ini dengan metode market adjusted model, diformulasikan sebagai berikut:

$$
\begin{aligned}
\mathrm{AR}= & \text { Rit }-\mathrm{E}(\mathrm{Rit}) \\
\mathrm{AR}= & \text { Abnormal return } \\
\mathrm{Ri}= & \text { Actual return saham } \mathrm{i} \\
\mathrm{E}(\mathrm{Rit})= & \text { Expected return berdasarkan indeks } \\
& \text { pasar IHSG }
\end{aligned}
$$

Hasil abnormal return yang positif memberikan arti bahwa tingkat keuntungan yang diperoleh para investor lebih tinggi dari pada yang diharapkan. Sedangkan abnormal return yang negatif, memberikan arti bahwa tingkat return yang diperoleh para investor lebih rendah dari pada yang diharapkan.

Faktor fundamental adalah faktor yang berkaitan langsung dengan kinerja emiten (perusahaan penerbit saham) itu sendiri. Semakin baik kinerja emiten maka semakin besar pengaruhnya terhadap kenaikan harga saham. Begitu juga sebaliknya, semakin menurun kinerja emiten maka semakin besar kemungkinan merosotnya harga saham yang diterbitkan dan diperdagangkan. Van Horne dalam Heru Sutojo (2005) beranggapan bahwa analisis fundamental pada dasarnya dapat dikatakan sebuah analisis yang dilakukan untuk melakukan penilaian atas sebuah saham, meliputi:

$$
\begin{aligned}
& 1=\text { Analisis Perekonomian Internasional } \\
& 2=\text { Analisis Perekonomian Nasional } \\
& 3=\text { Analisis Industri } \\
& 4=\text { Analisis Perusahaan. }
\end{aligned}
$$

Menurut Ali Arifin (2004) analisis fundamental adalah analisis saham yang dilihat dari sisi perusahaan (emiten) itu sendiri. Analisis ini didasarkan pada laporan keuangan (financial report) yang diterbitkan perusahaan.

Analisis fundamental adalah analisis sekuritas yang menggunakan data-data fundamental dan faktor-faktor eksternal yang berhubungan dengan badan usaha. Data fundamental yang dimaksud adalah data keuangan, data pangsa pasar, siklus bisnis, dan sejenisnya. Sementara data faktor eksternal 
yang berhubungan dengan badan usaha adalah kebijakan pemerintah, tingkat bunga, inflasi, dan sejenisnya. Analisis fundamental menghasilkan hasil analisis berupa penilaian badan usaha dengan kesimpulan apakah saham perusahaan tersebut layak dibeli atau tidak (Doddy Setiawan, 2003).

Dengan kata lain, analisis ini memfokuskan pada kinerja fundamental perusahaan penerbit saham (emiten) seperti rasio finansial dan kejadian-kejadian yang secara langsung maupun tidak langsung mempengaruhi kinerja keuangan perusahaan. Analisis fundamental berkaitan dengan kinerja perusahaan, tentang efektifitas dan efisiensi perusahaan mencapai sasarannya.

Untuk menganalisis kinerja perusahaan dapat digunakan rasio keuangan. Rasio keuangan membantu memahami data yang disajikan dalam laporan keuangan. Definisi rasio keuangan menurut Keown (2005) adalah:

"Mathematically, a financial ratio is nothing more than a ratio whose numerator and detrminator are comprice of financial data" Lebih lanjut menjelaskan tujuan rasio keuangan sebagai berikut. "The objective in using a ratio when analizing financial information is sumply to standardize the information analyzed so that comparisons can be made between ration of defferent firms or possibly thesame firm at different point in time"

Analisa rasio dapat mengungkapkan hubungan penting dan menjadi dasar perbandingan dalam menemukan kondisi dan tren yang sulit untuk dideteksi dengan mempelajari masing-masing komponen yang membentuk rasio (Wild, Subramanyam, dan Hasley dalam Yanivi S. Bachtiar dan S. Nurwahyu Harahap, 2005). Praktik bisnis yang nyata masih mengaplikasikan analisa rasio keuangan sebagai salah satu model analisis keuangan, meskipun relevansinya bersifat sangat subyektif, tergantung kepada tujuan dan kepentingan masing-masing analis (Bambang Agus Pramuka 2002).

Rasio keuangan digunakan untuk membandingkan risiko dan imbal hasil dari berbagai perusahaan untuk membantu investor membuat keputusan investasi yang baik (Wild at al, dalam Yanivi S. Bachtiar dan S. Nurwahyu Harahap, 2005). Salah satu tujuan dan keunggulan dari rasio adalah dapat digunakan untuk membandingkan hubungan return dan risiko dari perusahaan dengan ukuran yang berbeda. Rasio juga dapat menunjukkan profil suatu perusahaan, karakteristik ekonomi, strategi bersaing dan keunikan karakteristik operasi, keuangan dan investasi. Berikut dikutip beberapa rasio keuangan yang umum digunakan yang disadur dari buku The Analysis and Use of Financial Statements oleh Whild at.all dalam Yanivi S. Bachtiar dan S. Nurwahyu Harahap, (2005).

Penelitian ini menggunakan Prce Earning Ratio (PER) Operating Chas Flow (OCF), rasio debt atau leverage dijelaskan dengan debt to equity ratio (DER), sedangkan rasio profitabilitas diukur dengan rasio return on equity (ROE). Penelitian ini juga memsukkan ukuran perusahaan (Size) sebagai proksi ukuran perusahaan untuk mengukur apakah perusahaan besar lebih mampu mengahasilkan profit lebih besar dibandingkan dengan perusahaan kecil.

Hal ini sesuai dengan variabel yang digunakan oleh Sunarto (2001), namun ia memasukkan seluruh komponen rasio dan ditambahkan dengan rasio pasar. Demikian juga dengan Kennedy (2003) yang menggunakan seluruh rasio keuangan yang sesuai dengan analisis Dupont, serta Ullupi (2009) yang memasukkan rasio likuiditas, solvabilitas dan rentabilitas tanpa memasukkan unsur arus kas

\section{Oprating Cash Flow (OCF)}

PSAK No. 2 mendefinisikan arus kas sebagai berikut: "Arus kas adalah arus masuk dan arus keluar kas atau setara kas". Wild,et.all (2005) menyatakan bahwa :

"The statement of cash flows reports the cash receipts, cash payments, and net changes in cash resulting from the operating, investing, and financing activities of an enterprise during the period in a format that renconciles the beginning and ending cash balances".

Manfaat sesuai (PSAK No.2) laporan arus kas dapat memberikan informasi yang memungkinkan para pemakainya untuk 
mengevaluasi perubahan dalam aktiva bersih perusahaan, struktur keuangan perusahaan mengenai likuiditas dan solvabilitas, dan juga memiliki kemampuan untuk memengaruhi jumlah serta waktu arus kas dalam mengadaptasi terhadap perubahan keadaan dan peluang. Informasi arus kas berguna untuk menilai kemampuan perusahaan dalam menghasilkan kas dan setara kas serta memungkinkan para pemakai mengembangkan model untuk menilai dan membandingkan nilai sekarang dari arus kas masa depan (future cash flow) dari berbagai perusahaan. Informasitersebut juga meningkatkan daya banding pelaporan kinerja operasi berbagai perusahaan, karena dapat meniadakan pengaruh penggunaan perlakuan akuntansi yang berbeda terhadap transaksi dan peristiwa yang sama.

Arus kas diklasifikasikan menurut 3 (tiga) aktivitas yaitu :

\section{Aktivitas Operasi}

Adalah aktivitas penghasil utama pendapatan perusahaan dan aktivitas lain yang bukan merupakan aktivitas investasi dan aktivitas pendanaan, seluruh transaksi dan peristiwaperistiwa lain yang tidak dianggap sebagai kegiatan investasi atau pendanaan. Kegiatan ini biasanya mencakup kegiatan produksi, pengiriman barang, dan pemberian jasa.

Contoh arus kas masuk dari aktivitas operasi :

a) Penerimaan kas dari penjualan barang dan jasa, termasuk penerimaan dari piutang akibat penjualan, baik jangka panjang atau jangka pendek

b) Penerimaan dari bunga pinjaman dan penerimaan dari surat berharga lainnya, seperti bunga atau dividen.

Contoh arus kas keluar dari aktivitas operasi :

a) Pembayaran kas untuk membeli bahan yang akan digunakan untuk produksi atau untuk dijual, termasuk pembayaran utang jangka pendek atau jangka panjang ke supplier

b) Pembayaran kas kepada supplier lain dan pegawai untuk kegiatan selain produksi barang dan jasa

c) Pembayaran kas kepada pemerintah untuk pajak, kewajiban lainnya, denda, dan lainlain.

\section{Aktivitas Investasi}

Termasuk dalam arus kas dari kegiatan investasi adalah perolehan dan pelepasan aktiva jangka panjang serta investasi lain yang tidak termasuk setara kas, antara lain menerima dan menagih pinjaman utang, surat-surat berharga ataupun modal, aktiva tetap dan aktiva produktif, lainnya yang digunakan dalam proses produksi.

Contoh arus kas masuk dari aktivitas investasi :

a) Penerimaan kas dari penjualan tanah, bangunan dan peralatan, aktiva tak berwujud, dan aktiva jangka panjang lain

b) Penjualan investasi saham dan lainnya.

Contoh arus kas keluar dari aktivitas investasi :

a) Pembayaran kas untuk membeli aktiva tetap, aktiva tak berwujud, dan aktiva jangka panjang lain

b) Pembelian saham perusahaan lain atau perusahaan sendiri.

\section{Aktivitas Pendanaan}

Adalah aktivitas yang mengakibatkan perubahan dalam jumlah serta komposisi modal dan pinjaman jangka panjang perusahaan. Kegiatannya berupa mendapatkan sumbersumber dana dari pemilik dengan memberikan prospek penghasilan dari sumber dana tersebut, meminjam dan membayar utang kembali, atau melakukan pinjaman jangka panjang untuk membayar utang tertentu.

Contoh arus kas masuk dari aktivitas pendanaan:

a) Penerbitan dan pengeluaran surat berharga dalam bentuk equity

b) Penerbitan dan pengeluaran obligasi, hipotek, wesel, dan pinjaman jangka panjang lainnya.

Contoh arus kas keluar dari aktivitas pendanaan:

a) Pembayaran dividen kepada pemegang saham

b) Pembayaran kas oleh penyewa guna usaha (lessee) untuk mengurangi saldo kewajiban yang berkaitan dengan sewa guna pembiayaan (finance lease).

Semakin meningkatnya Operating 
Cash Flow (OCF), memcerminkan kemampuan perusahaan dalam menghasilkan kas untuk melunasi pembayaran atau pengeluaran kas. Dengan demikian kinerja perusahaan akan semakin meningkat. Meningkatnya kinerja perusahaan memberikan respon positif bagi investor, yang mengakibatkan meningkatnya harga saham. Semakin meningkatnya harga saham dengan sendirinya meningkatkan abnormal return saham. Hal ini berarti bahwa jika Operating Cash Flow (OCF) meningkat, abnormal return juga akan meningkat.

\section{Price Earning Ratio (PER)}

Zaenal Arifin (2005) mendefinisikan price earning ratio sebagai cerminan dari beberapa besar uang yang berani dibayar oleh investor untuk setiap lembar saham. Dengan demikian, apabila $\mathrm{P} / \mathrm{E}$ ratio menunjukan angka yang tinggi maka investor bersedian membayar lebih mahal untuk setiap lermbar saham. Demikian juga sebaliknya apabila $\mathrm{P} / \mathrm{E}$ ratio rendah menunjukkan bahwa investor bersedia untuk membayar lebih murah untuk setiap lembar saham.

Price earning ratio merupakan rasio yang lazim dipakai untuk mengukur harga pasar setiap lembar saham biasa dengan laba per lembar saham. PER didapat harga saham yang dibagi dengan laba per lembar saham. Price earning ratio (PER) sering dipakai untuk mengelompokkan saham berdasarkan tingkat pertumbuhannya. Saham dengan tingkat pertumbuhan yang tinggi umumnya memiliki price earning ratio (PER) yang tinggi pula. Dengan kata lain investor bersedia membeli saham dengan price earning ratio (PER) yang tinggi karena mereka mengharapkan aliran kas masuk lebih besar di masa yang akan datang.

Rasio ini menggambarkan ketersediaan investasi membayar suatu jumlah tertentu untuk setiap perolehan laba perusahaan. Price earning ratio dapat dihitung dengan perbandingan antara harga pasar per lembar saham dan laba bersih per lembar saham. Rasio ini diperoleh dengan menggunakan rumus sebagai berikut :

PER $=\frac{\text { Harga Saham Per Lembar }}{\text { Laba Per lembar saham }}$
Keterangan :

Earning per share $(E P S)=\frac{\text { Laba Bersih }}{\text { Jumlah Saham Beredar }}$

Informasi penting yang harus diperhatikan dalam analisis perusahaan adalah laba per lembar saham atau lebih dikenal sebagai Earning Per Share (EPS). Dengan menggunakan laporan keuangan investor juga akan bisa menghitung berapa besarnya pertumbuhan earning yang telah dicapai perusahaan terhadap jumlah saham perusahaan. Perbandingan antara jumlah earning (dalam hal ini laba bersih yang siap dibagikan bagi pemegang saham) dengan jumlah lembar saham perusahaan akan diperoleh komponen Earning Per Share (EPS). Bagi para investor informasi EPS merupakan informasi yang dianggap paling mendasar dan berguna, karena bisa menggambarkan prospek earning perusahaan di masa depan (Eduardus Tendellilin, 2010).

Price Earning Ratio (PER) digunakan dalam pemilaian return saham, PER mencerminkan beberapa besar uang yang berani dibayar oleh investor untuk setiap lembar saham. Price Earning Ratio (PER) biasanya terkait dengan tahap pertumbuhan perusahaan, sehingga perusahaan-perusahaan yang sedang berada dalam tahap pertumbuhan biasanya memiliki nilai PER yang lebih tinggi. Rasio ini sebagai alat ukur untuk menilai tingkat pertumbuhan perusahaan.

Semakin meningkatnya Price Earning Ratio (PER) memceriminkan pertumbuhan perusahaan. Hal ini menunjukkan kinerja perusahaan akan semakin meningkat. Meningkatnya kinerja perusahaan memberikan respon positif bagi investor, yang mengakibatkan meningkatnya harga saham. Semakin meningkatnya harga saham dengan sendirinya meningkatkan abnormal return saham. Hal ini berarti bahwa jika Price Earning Ratio (PER) meningkat, abnormal return juga akan meningkat.

\section{a. Return On Equity (ROE)}

Return On Equity atau return on net worth adalah salah satu indikator dalam menghitung rasio profitabilitas. ROE mengukur kemampuan 
perusahaan memperoleh laba yang tersedia bagi pemegang saham perusahaan (earning available for common stockholder's) agar dapat terlihat kemampuan modal sendiri dalam mengahasilkan laba, maka diperlukan perhitungan laba bersih yang telah dikurangi dengan biaya bunga dari modal asing (cost of debt) dan pajak perseroan (income tax). Sedangkan modal yang dihitung adalah modal sendiri yang bekerja dalam perusahaan. Rasio ini juga dipengaruhi oleh besar kecilnya utang perusahaan, apabila proporsi utang makin besar maka rasio ini juga akan makin besar. (Husnan, 2003).

Return On Equity adalah rasio untuk mengukur seberapa efektif perusahaan memanfaatkan kontribusi pemilik dan atau seberapa efektifnya perusahaan memenfaatkan sumber-sumber lain untuk kepentingan pemilik. Rumus untuk ROE yaitu dengan membagi Net Income After Tax (NIAT) dengan shareholder' equity (Brigham dan Houston dalam Ali Akbar Yulianto (2004).

$\mathrm{ROE}=\frac{\text { Earning after Tax and Interest }}{\text { Equity }}$

Dari sudut pandang investor ROE merupakan salah satu indikator penting untuk menilai prospek perusahaan di masa yang akan datang. Dengan mengetahui tingkat ROE, investor dapat melihat pertumbuhan profitablitas perusahaan. Indikator ROE sangat penting diperhatikan untuk mengetahui investasi yang akan dilakukan investor di suatu perusahaan mampu memberikan return yang sesuai dengan tingkat yang diharapkan, ROE akan berubah jika eraning after tax atau equity berubah.

Dalam menentukan pilihannya, investor biasanya akan mempertimbangkan perusahaan yang mampu memberikan kontribusi ROE yang lebih besar. Bagi investor semakin tinggi ROE menunjukkan risiko investasi semakin kecil. Atau dengan kata lain dikatakan bahwa semakin tinggi ROE akan mengakibatkan beta saham tersebut semakin rendah, sebaliknya ROE yang rendah akan mengakibatkan beta sahamnya semakin tinggi.

Indikator ROE yang meningkat sangat penting diperhatikan untuk mengetahui investasi yang akan dilakukan investor. Dengan ROE yang tinggi suatu perusahaan mampu memberikan return sesuai dengan tingkat yang diharapkan; meningkatnya ROE akan meningkatkan abnormal return saham.

\section{b. Debt to Equity Ratio (DER)}

Financial leverage menunjukkan kemampuan perusahaan dalam membayar hutang dengan equity yang dimilikinya. Tingginya financial leverage menunjukkan risiko finansial atau risiko kegagalan perusahaan untuk mengembalikan pinjaman akan semakin tinggi, dan sebaliknya. Perusahaan yang tidak mempunyai leverage berarti menggunakan modal sendiri 100 \%. Menurut Ina Listtiorini (2008), penggunaan utang itu sendiri bagi perusahan mempunyai tiga dimensi, yaitu (1) pemberi kredit akan menitikberatkan pada besarnya jaminan atas kredit yang diberikan, (2) dengan menggunakan utang maka apabila perusahaan mendapatkan keuntungan yang lebih besar dari beban tetapnya maka pemilik perusahaan keuntungannya akan meningkat, (3) dengan menggunakan utang maka pemilik memperoleh dana dan tidak kehilangan pengendalian atas perusahaan.

Eckbo dan Norli dalam http:/www. ssrn.com (2004) menyimpulkan adanya respon return saham terhadap faktor yang berhubungan dengan leverage. Li et al. dalam http://www.ssrn. com (2005) menemukan bahwa risiko delisting perusahaan berhubungan positif dengan financial leverage dan berhubungan negative dengan biaya riset dan pengembangan serta gross margin perusahaan.

Financial leverage yang digunakan dalam penelitian ini adalah Debt to Equity Ratio (DER). Setiap sumber dana selalu mempunyai biaya masing-masing yang biasa disebut cost of fund. Pada saat akan digunakan, dana dari luar perusahaan dalam bentuk hutang biasanya akan timbul biaya-biaya (cost of debt) yang harus ditanggung sebesar biaya bunga. Sementara jika dari modal sendiri (equity) akan timbul biaya yang merupakan opportunity cost dari modal tersebut. Mengingat begitu bervariasinya biaya 
dari luar maupun dari dalam perusahaan, maka perlu dipertimbangkan sumber pembiayaan dalam investasi.

Alat analisis yang digunakan untuk mengetahui besarnya perusahaan memiliki financial risk adalah dengan menggunakan Debt to Equity Ratio (DER).

Debt equity ratio menunjukan seberapa besar aktiva perusahaan dibiayai oleh hutang atau seberapa besar hutang perusahaan berpengaruh terhadap penggelolaan akutias. Debt equity ratio diperoleh dengan total hutang dibagi dengan total ekuitas, setiap rupiah modal dijadikan jaminan untuk keseluruhan utang. (Van Horne dalam Heru Sutojo, 2005), dapat diukur dengan rumus sebagai berikut.

$$
\mathrm{DER}=\frac{\text { Total Liabilities }}{\text { Equity }}
$$

DER yang semakin besar akan mengakibatkan risiko financial perusahaan semakin tinggi. Dengan penggunaan hutang yang semakin besar akan mengakibatkan semakin tinggi risiko untuk tidak mampu membayar hutang. Investor biasanya menghidari risiko, maka semakin tinggi DER akan mengakibatkan saham perusahaan tersebut dihindari investor, sehingga harga saham semakin rendah. Dengan kata lain dapat dikatakan bahwa hubungan DER dengan beta saham adalah positif, artiya semakin tinggi tingkat DER akan mengakibatkan semakin tinggi risiko pasar dan sebaliknya tingkat DER yang rendah akan mengakibatkan risiko sahamnya rendah.

Meningkatnya Debt to Equity Ratio (DER) berarti akan meningkatkan resiko berinvestasi, dengan demikian investor merespon negatif terhadap kinerja perusahaan. Rendahnya kinerja perusahaan berakibat harga saham semakin menurun. Menurunnya harga saham mengakibatkan abnormal return yang semakin menurun.

\section{c. Size}

Menurut Agnes Sawir (2004) Ukuran perusahaan dinyatakan sebagai determinan dari struktur keuangan dalam hampir setiap studi dan untuk sejumlah alasan berbeda. Pertama, ukuran perusahaan dapat menentukan tingkat kemudahan perusahaan memperoleh dana dari pasar modal. Perusahaan kecil umumnya kekurangan akses ke pasar modal yang terorganisir, baik untuk obligasi maupun saham. Kalaupun mereka punya akses, biaya peluncuran dari penjualan sejumlah kecil sekuritas dapat menjadi penghambat. Jika penerbitan sekuritas dapat dilakukan, sekuritas perusahaan kecil mungkin kurang dapat dipasarkan sehingga membutuhkan penentuan harga sedemikian rupa agar investor mendapatkan hasil yang memberikan return lebih tinggi secara signifikan.

Kedua, ukuran perusahaan menentukan kekuatan tawar-menawar dalam kontrak keuangan. Perusahaan besar biasanya dapat memilih pendanaan dari berbagai bentuk hutang, termasuk penawaran spesial yang lebih menguntungkan dibandingkan yang ditawarkan perusahaan kecil. Semakin besar jumlah uang yang terlibat, semakin besar kemungkinan pembuatan kontrak yang dirancang sesuai dengan preferensi kedua pihak sebagai ganti dari penggunaan kontrak standar hutang. Ketiga, ada kemungkinan pengaruh skala dalam biaya dan return membuat perusahaan yang lebih besar dapat memperoleh lebih banyak laba.

Beberapa perusahaan melihat size perusahaan dari total asset, sementara perusahaan lain menggunakan pendapatan dan ukuran pasar. Ukuran aktiva dipakai sebagai wakil pengukur (proxy) besarnya perusahaan. Perusahaan yang besar dianggap mempunyai risiko yang lebih kecil dibandingkan dengan perusahaan yang kecil. Alasannya adalah bahwa perusahaan yang besar mempunyai akses ke pasar modal, sehingga dianggap mempunyai Beta yang lebih kecil. Anggapan ini merupakan anggapan yang umum, tidak didasarkan pada teori. Namun demikian Watts dan Zimmerman (1986), dalam Wiwik Utami (2001), mencoba membuktikan risiko dengan asset ini untuk membentuk suatu teori yang disebut teori akuntansi positif (Positive accounting theory). Perusahaan yang besar merupakan subyek dari tekanan politik. Perusahaan yang melaporkan laba yang 
tinggi menarik perhatian politikus dan akan diinvestigasi karena dicurigai melakukan praktek monopoli. Oleh karena itu perusahaan besar cenderung menginvestasikan dananya ke proyek yang mempunyai varian rendah dengan beta yang rendah untuk menghindari laba yang berlebihan.

Sedangkan menurut Suad Husnan (2003), total asset cenderung berpengaruh negatif terhadap harga saham. Hal ini berkaitan dengan kecenderungan size effect yaitu kecenderungan perusahaan kecil memperoleh keuntungan yang lebih besar dibandingkan dengan perusahaan besar.

\section{Metode}

Penelitian ini menggunakan jenis data sekunder, yang didapatkan dari Indonesian Capital Market Directory (ICMD) Perusahaan Makanan dan minuman yang terdaftar di Bursa Efek Indonesia (BEI) tahun 2011-2015. Total sampel awal dalam penelitian ini sebanyak 75 sampel,namun setelah diseleksi sesuai dengan kriteria kebutuhan data dan melalui beberapa pengujian hanya terdapat 55 sampel yang digunakan. Kriteria seleksi samoel sebagaimana tampak pada tabel 1. Pengujian hipotesis dilakukan dengan pengujian regresi linier sebagai berikut:

$$
\begin{aligned}
& \mathrm{AR}=\alpha-\beta 1 \mathrm{OCF}+\beta 2 \mathrm{PER}+\beta 3 \mathrm{ROE}+\beta 4 \mathrm{DER}+ \\
& \beta 5 \mathrm{SIZE}+\mathrm{e}
\end{aligned}
$$

Keterangan :

$\mathrm{AR}=$ abnormal return

$\alpha=$ konstanta

$\beta(1-5)=$ Koefisien Regresi

$\mathrm{X}_{1}=$ Operating Cash Flow (OCF)

$\mathrm{X}_{2}=$ Price Eraning Ratio (PER)

$\mathrm{X}_{3}=$ Return on Equity (ROE)

$\mathrm{X}_{4}=$ Debt Equity Ratio (DER)

$\mathrm{X}_{5}=$ Size

$\mathrm{e}=$ Error Term

Penelitian ini menggunakan pengujian asumsi klasik dan uji hipotesis.

\section{Tabel 1. Kriteria dan Hasil Pemilihan Sampel Perusahaan}

\begin{tabular}{ll}
\hline Perusahaan Makanan dan Minuman yang terdaftar di Bursa Efek Indonesia & 15 \\
(BEI) pada tahun 2011-2015 & 75 \\
Jumlah sampel & 4 \\
Perusahaan yang tidak memiliki variabel lengkap sesuai yang dibutuhkan & \\
(Operating chas flow, PER, ROE, DER dan Total Assets). & 11 \\
Jumlah populasi & 55 \\
\hline
\end{tabular}

\begin{tabular}{|c|c|c|c|c|}
\hline Variabel & Dimensi & Indikator & Skala & Referensi \\
\hline \multicolumn{5}{|c|}{$\begin{array}{l}\text { Variabel Independen } \\
(\mathrm{X})\end{array}$} \\
\hline $\mathrm{OCF}\left(\mathrm{X}_{1}\right)$ & $\begin{array}{l}\text { Total Cash Flow } \\
\text { from operation }\end{array}$ & $\begin{array}{l}\text { Perubahan OCF meng- } \\
\text { gambarkan kemampuan } \\
\text { perusahaan dalam } \\
\text { menghasilkan keuangan } \\
\text { internal }\end{array}$ & Rasio & $\begin{array}{l}\text { Wild et.al (1997) } \\
\text { Harahap (2004) }\end{array}$ \\
\hline $\operatorname{PER}\left(\mathrm{X}_{2}\right)$ & Profitabilitas & $\begin{array}{l}\text { Perubahan PER meru-pakan } \\
\text { perubahan rasio harga pasar } \\
\text { setiap lembar saham }\end{array}$ & Rasio & $\begin{array}{l}\text { Zaenal Arifin, } \\
(2005)\end{array}$ \\
\hline
\end{tabular}

Tabel 2. Variaber Penelitian 


$\begin{array}{llll}\text { Harga saham } & \begin{array}{l}\text { dengan laba per lembar } \\ \text { EPS }\end{array} & \begin{array}{l}\text { saham. Semakin besar PER } \\ \text { menunjukkan } \quad \text { semakin }\end{array} & \text { Jogiyanto (2003) } \\ & \text { mahal harga saham dan Rasio } & \text { Tandellin (2010) } \\ \text { EPS }=\text { Jmlh saham } & \begin{array}{l}\text { semakin kecil keuntungan } \\ \text { akuntansinya }\end{array} & & \end{array}$

Perubahan ROE me-rupakan

kemampuan perusahaan

memberikan keuntungan

kepada pemegang saham.

Profitabilitas Perubahan ROE dihitung

dengan membandingkan

antara laba bersih

Brigham (2001),

$\operatorname{ROE}\left(\mathrm{X}_{3}\right) \quad \frac{\text { EAT }}{\text { Equity }}$

dan ekuitas. Tingkat

pengembalian ekuitas atas

perolehan laba selama

periode akuntansi.

Perubahan DER me-rupakan

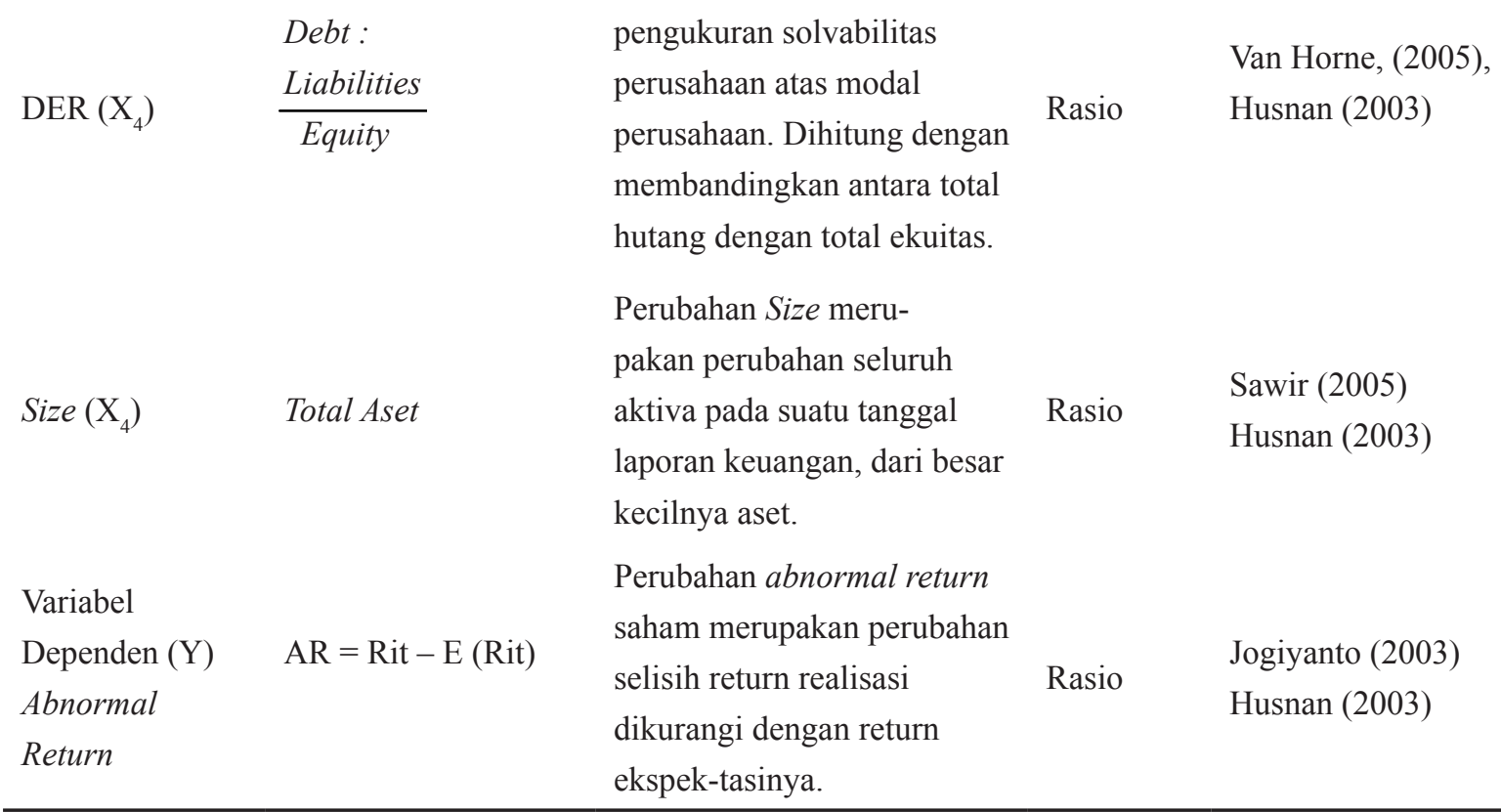

Sumber: berbagai pendapat dan publikasi, dikembangkan untuk penelitian.

Teknik analisis dilakukan dengan uji regresi linier berganda. Tahapan pengujian mencakup uji asumsi klasik, uji model penelitian, dan uji hipotesis penelitian. Uji asumsi klasik terdiri dari uji normalitas, uji multikolinearitas, uji heteroskedastisitas dan uji autokorelasi. Uji asumsi klasik dilakukan uji Normalitas pada dasarnya dilakukan dengan tujuan mengetahui normal tidaknya distribusi residual dari model regresi variabel. Model regresi yang baik adalah memiliki distribusi data normal atau mendekati normal. Untuk melihat normalitas data dapat digunakan Kolmogorov-Smirnov Test, yaitu membandingkan nilai asymptotic significance 
dengan $\alpha=5 \%$. Data dikatakan berdistribusi normal jika nilai asymp. sig 2-tailed $>0,05$.

Uji multikolinearitas dimaksudkan untuk menentukan ada tidaknya asosiasi (hubungan) antara dua variabel independen atau lebih. Tujuan dari pengujian ini adalah untuk mengetahui terjadinya korelasi antar variabel - variable independen dalam penelitian. Dalam model regresi yang baik seharusnya tidak terjadi hubungan linear yang nyata (korelasi) antar variabel independen. Metode pengujian dengan melihat nilai Variance Inflation Factor (VIF) dan tolerance. Jika nilai VIF mendekati 1 maka tidak terjadi multikolinearitas (model regresi baik).

Uji heterokedastisitas bertujuan untuk menge tahui terjadinya ketidaksamaan varians pada residual dari model regresi. Jika varians tidak sama, dikatakan terjadi heteroskedastisitas. Model regresi yang baik adalah model regresi yang homoskedastisitas atau tidak terjadi heteroskedastisitas.

Uji autokorelasi bertujuan untuk menguji residual dari model regresi dalam menemukan korelasi antara kesalahan pengganggu pada periode $\mathrm{t}$ dengan kesalahan pengganggu pada periode $\mathrm{t}-1$. Model regresi dikatakan baik jika bebas dari autokorelasi. Untuk mendeteksi ada tidaknya autokorelasi dalam model regresi dengan melihat besarnya nilai D-W (Durbin-Waston). Keputusan didapatkan dengan melihat jumlah sampel yang diteliti kemudian melihatangka hasil pengujian pada Durbin-Watson test dan dibandingkan dengan angka pada Durbin-Watson table (nilai signifikansi $5 \%$ atau 0,05 ). Yang mana kriteria pengujian autokorelasi di tabel 3 .
Uji Model penelitian dilakukan dengan uji koefisien determinasi dan Uji F. Semakin tinggi nilai koefisien determinasi, maka kemampuan variable independen menjelaskan dependen variable semakin besar. Uji merupakan pengujian variable independen secara bersamaan dengan variable dependen, jika hasil uji $\mathrm{F}$ berpenaruh maka model dikatakan baik (fit). Uji hipotesis 1 sampai dengan hipotesis 3 diuji dengan uji-t. Pengujian ini digunakan untuk mengetahui ada tidaknya pengaruh masing-masing variabel independen terhadap variabel dependen.

\section{Hasil Penelitian dan Pembahasan}

Statistik deskriptif menggambarkan profil data sampel yang meliputi rata - rata (mean), nilai terendah (minimum), nilai tertinggi (maximum), dan standar deviasi (standard deviation). Dalam pengujian statistic deskriptif dengan menggunakan sampel sebanyak 11 perusahaan Makanan dan Minuman yang terdaftar di Bursa Efek Indonesia periode tahun 2011 - 2015. Statistik deskriptif dari data tersebut adalah sebagai berikut: (tabel 4).

Variabel abnormal return saham (AR) dari 55 sampel perusahaan industri makanan dan minuman yang terdaftar di BEI tahun 2011 sampai 2015 berkisar antara -14 sampai 2,06. Nilai rata-rata sebesar 0,6865 , standar deviasi sebesar 0,6756. Berdasarkan nilai rata-rata dapat disumpulkan bahwa pertumbuhan abnormal return perusahaan makanan dan minuman sebesar $0,68 \%$.

\section{Tabel 3 : Pengambilan Keputusan Uji Autokorelasi}

\begin{tabular}{ccc}
\hline Hipotesis & Hasil Estimasi & Kesimpulan \\
\hline Ho & $0<\mathrm{dw}<\mathrm{dl}$ & Tolak \\
Ho & $\mathrm{dl} \leq \mathrm{dw} \leq \mathrm{du}$ & Tidak ada kesimpulan \\
$\mathrm{H}_{1}$ & $4-\mathrm{dl}<\mathrm{dw}<4$ & Tolak \\
$\mathrm{H}_{1}$ & $4-\mathrm{du} \leq \mathrm{dw} \leq 4-\mathrm{dl}$ & Tidak ada kesimpulan \\
Tidak ada korelasi, baik positif maupun negatif & $\mathrm{du}<\mathrm{dw}<4-\mathrm{du}$ & Diterima \\
\hline
\end{tabular}

Sumber: Ghozali, I. (2007). 
Tabel 4. Deskripsi Variabel Penelitian

\begin{tabular}{lrrrr}
\hline Variabel & Minimum & Maximum & \multicolumn{1}{l}{ Mean } & \multicolumn{1}{c}{ Std. Deviation } \\
\hline AR & $-0,14$ & 2,06 & 0,68 & 0,67 \\
OCF $\left.^{*}\right)$ & 0,0032 & 2,68 & 0,31 & 0,63 \\
PER & $-10,77$ & 33,04 & 76,51 & 443,44 \\
ROE & 0,03 & 143,53 & 17,95 & 26,61 \\
DER & 0,08 & 3,03 & 0,96 & 0,54 \\
SIZE & 5,35 & 18,34 & 13,36 & 3,09 \\
\hline
\end{tabular}

*) dalam milyar rupiah

Variabel Operating cash flow (OCF) mempunyai rata-rata sebesar Rp. 310.506.491 milyar dengan OCF minimal sebesar Rp 310.506.491 milyar dan maksimal Rp. 2.684.806.000 milyar, sedangkan standar deviasinya sebesar Rp. 619.788.729.milyar. Berdasarkan nilai rata-rata dapat disumpulkan bahwa perusahaan yang dijadikan sampel mampu menghasilkan kas guna membiayai kebutuhan operasionalnya sebesar $\mathrm{Rp}$ 310.506.491 milyar.

Variabel Price Earning Ratio (PER) mempunyai persentase rata-rata sebesar 76.5087 dengan nilai minimal sebesar -10.77dan maksimal 33,04, sedangkan standar deviasinya sebesar 76.5087. Berdasarkan nilai rata-rata dapat disumpulkan bahwa apresiasi pasar terhdap kemampuan perusahaan menghasilkan laba sebesar $76.5087 \%$, atau pasar menghargai 0,76 kali atas kemampuan perusahaan menghasilkan laba.

Variabel Return on Equity (ROE) mempunyai persentase rata-rata sebesar 17.9485 dengan nilai minimal sebesar $0, .03$ dan maksimal 143.53, sedangkan standar deviasinya sebesar 26.60811. Berdasarkan nilai rata-rata dapat disumpulkan bahwa kemampuan perusahaan menghasilkan laba bagi para pemegang saham, yang dapat dilihat dari kemampuan modal sendiri dalam menghasilkan laba sebesar 17.94 kali.

Variabel Debt to Equity Ratio (DER) mempunyai persentase rata-rata sebesar 0.9587 dengan nilai minimal sebesar 0,08 dan maksimal 3.03, sedangkan standar deviasinya sebesar 0,9587 . Berdasarkan nilai rata-rata dapat disumpulkan bahwa kemampuan perusahaan dalam memenuhi kuwajibannya dengan equity yang dimilikinya sebesar 95,87 kali.Ukuran perusahaan (size) yang dinyatakan dengan nilai total aset dalam penelitian ini adalah jumlah total aktiva lancar dan total aktiva tetap emiten. Ratarata total aset perusahaan Rp. 13.3612 milyar, dengan total aset minimum Rp. 5.35 milyar dan maksimum Rp. 18.34 milyar dan sandar deviasi sebesar 3.09035 r. Berdasarkan nilai rata-rata dapat disimpulkan bahwa ukuran perusahaan selama periode penelitian perusahaan obyek penelitian sebesar Rp. 13.3612 milyar.

Uji hipotesis dilakukan untuk menguji pengaruh variabel independen yang dalam penelitian ini menggunakan OCF, PER,ROE, DER, dan Size terhadap variabel dependen Abnormal Return. Pengujian hipotesis akan membawa kepada kesimpulan untuk mendukung atau tidak mendukung hipotesis. Hasil kesimpulan disesuaikan dengan hipotesis berikut: (tabel 5).

Berdasarkan nilai signifikansi variabel independen di atas, secara parsial variabel PER (Price Earning Ratio) memiliki nilai signifikansi 0,039 , variable ROE memiliki nilai signifikansi 0,007, variable DER memiliki nilai signifikansi 0,009 , variable Size memiliki nilai signifikansi 0,000 dan variable OCF (Operating Chas Flow) memiliki nilai signifikansi 0,319. Artinya variable PER, ROE, DER dan Size berpengaruh terhadap abnormal return, hanya variabel OCF tidak berpengaruh terhadap abnormal return. Hanya variable DER yang berpengaruh negatif terhadap abnormal return. Sedangkan secara simultan variable OCF, PER, ROE, DER an Size memiliki nilai signifikansi 0,000 , Artinya secara simultan berpengaruh terhadap abnormal return. Hal ini berarti bahwa model yang diuji baik (fit). 
Tabel 5. Hasil Uji Hipotesis

\begin{tabular}{|c|c|c|c|c|c|c|c|}
\hline $\mathrm{y}^{\wedge}$ & $=$ & $\alpha$ & $+\beta 1 \mathrm{OCF}$ & $+\beta 2$ PER & $+\beta 3 \mathrm{ROE}$ & $+\beta 4$ DER & $+\beta 5$ Size \\
\hline & $=$ & & (1) & (2) & (3) & (4) & (5) \\
\hline b & $=$ & 1.090 & -0.055 & +0.506 & +0.320 & -0.33 & +0.747 \\
\hline tstat & $=$ & 1.100 & -1.005 & +2.118 & 2.787 & 2.734 & 6.739 \\
\hline p-value & $=$ & 0.027 & 0.319 & $0.039 * *$ & 0.007 & $0.009 *$ & $0.000 *$ \\
\hline $\mathrm{R}$ & $=$ & 0.773 & & & & & \\
\hline R Square & $=$ & 0.598 & & & & & \\
\hline Adj. R Sqr & $=$ & 0.561 & & & & & \\
\hline Fstat & $=$ & 16.069 & & & & & \\
\hline P-value & & $0.000 *$ & & & & & \\
\hline DW & $=$ & 1.891 & & & & & \\
\hline$*$ & & Signifi & da $\alpha=1 \%$ & & & & \\
\hline$* *$ & & Signifi & da $\alpha=5 \%$ & & & & \\
\hline t tabel & & $(d f=5$ & $1 \%$; one t & & 1.297 & & \\
\hline $\mathrm{t}$ tabel & & $(\mathrm{df}=5$ & $5 \%$; one t & & 1.674 & & \\
\hline F tabel & & $(d f=5$ & $1 \%$; one t & & 2.386 & & \\
\hline
\end{tabular}

Operating Cash Flow $\left(\mathrm{X}_{1}\right)$ secara parsial memberikan pengaruh negatif dan tidak signifikan terhadap abnormal return saham (Y). Hasil ini mengindikasikan bahwa informasi operating cash flow kurang menarik bagi investor dalam menilai return saham. Penelitian ini mendukungi penelitian terdahulu yang dilakukan oleh Sri Wahyuni (2002), dan Hadri Kusuma dan Rahardjo (2004).

Price Earning Ratio $\left(\mathrm{X}_{2}\right)$ memberikan pengaruh positif dan signifikan terhadap abnormal return saham (Y). Hasil ini mengindikasikan bahwa informasi price earning ratio menarik bagi investor dalam menilai return saham. Penelitian ini mendukung penelitian Aydogan dan Gursoy (2002), Nainggolan (2004), Aga dan Kocaman (2006), Huang dan Chen (2007) dan Hadianto (2008), tetapi berbeda dengan penelitian yang dilakukan oleh Abidin (2009).

Return on Equity memberikan pengaruh positif dan signifikan terhadap abnormal return saham (Y). Hasil ini mengindikasikan bahwa informasi return on equity menarik bagi investor dalam menilai return saham. Penelitian ini mendukung penelitian sebelumnya oleh Sunarto (2001) dan Nainggolan (2004), tetapi berbeda dengan penelitian yang dilakukan oleh Anastasia (2003), Noersasongko dan Wulandari (2006), dan Abidin (2009).

Debt to Equity Ratio memberikan pengaruh negatif dan signifikan terhadap abnormal return saham (Y). Hasil ini mengindikasikan bahwa informasi debt to equity ratio menarik bagi investor dalammenilai return saham. Penelitian ini mendukung penelitian terdahulu yang dilakukan oleh Nainggolan (2004), Kartika (2007), Ullupui (2009), Sivaprasad dan Muradoglu (2010), tetapi berbeda dengan penelitian yang dilakukan oleh Michel Suhardi (2005), Gomes dan Schmid (2008), Abidin (2009).

Size memberikan pengaruh positif dan signifikan terhadap abnormal Return saham (Y). Hasil ini mengindikasikan bahwa informasi size menarik bagi investor dalam menilai return saham. Ukuran perusahaan (Size) yang diproksi total aset mempunyai pengaruh yang paling domian terhadap abnormal return saham. Hal ini berarti ukuran perusahaan (Size) merupakan tolok ukur yang lebih baik dalam menilai abnormal return saham perusahaan food and beverages. Penelitian ini mendukung penelitian terdahulu yang dilakukan oleh Kartika (2007), tetapi berbeda dengan penelitian Senthilkumar (2009).

Saran untuk penelitian selanjutnya dengan topik yang sama yaitu pertama menggunakan lebih banyak sampel untuk menunjang 
keakuratan hasil pengujian dalam penelitian. Kedua, menambahkan sektor perusahaan lain, sehingga memperluas penelitian tidak hanya di sektor perusahaan makanan dan minuman dan kesimpulan yang didapatkan lebih bersifat umum. Ketiga, bila perlu gunakan sampel perusahaan asing (perusahaan yang berada di luar negeri) untuk melihat seberapa jauh perusahaan - perusahaan di suatu negara dalam menentukan Abnormal Return.

\section{Daftar Rujukan}

Abidin, J., 2009. Analisis Faktor Fundamental Keuangan dan Risiko Sistematik Terhadap Harga Saham Perusahaan Consumer Goods yang Terdaftar di Bursa Efek Indonesia. Tesis, Program Pasca Sarjana, Universitas Sumatera Utara, Medan.

Anastasia, N., 2003, Analisis Analisis Faktor Fundamental dan Risiko Sistematk terhadap Harga Saham properti di BEJ, Jurnal Ekonomi Akuntansi dan Keuangan Vol.5 No.

2 Nopember 2003: 123-132.

Arikunto, S., 2002. Prosedur Penelitian Suatu Pendekatan Praktek, Edisi Revisi. Rineka Cipta, Jakarta.

Aydogan dan Gursoy 2000, International Research Journal of Finance and Economics C.EuroJournal Publising,Inc, http//ssrn.com/ abstract 597922.

Brigham, H., 2001. Fundamentals of Financial Management, $10^{\text {th }}$ Edition. Diterjemahkan oleh Ali Akbar Yulianto, Salemba Empat, Jakarta

Bursa Efek Indonesia, historical composite index, http://finance yahoo.com.

Eckbo, B. Espen dan Oyvind Norli, 2004). Liquidity Risk, Leverage and Long-run IPO Return. Available, http://www.ssrn.com

Ghozali, I. (2007). Aplikasi Analisis Multivariate dengan Program SPSS. Cetakan Keempat. Semarang: Badan Penerbit Universitas Diponegoro.

Gomes and Lucas Schmid, November 2008, JLL, Levered Returns, The Wharton School,University of Pennsylvania, The
Fuqua School of Business, Duke University. Harahap, S. S., 2004, Analisis Kritis Atas Laporan Keuangan, Edisi Pertama, Cetakan Keempat, PT Raja Grafindo Persada Jakarta.

Hermansyah, I., Ariesanti, E., 2008, Pengaruh Laba Bersih Terhadap Harga Saham, Jurnal Akuntansi FE, Unsil, Vol 3 No. 1 2008, issn 1907-9958, hal 390-396.

Horne, V.C. J. and Wachowicz, Jr., M. John, (2005), Prinsip-prinsip Manajemen Keuangan. Buku Satu, Edisi Indonesia, diterjemahkan oleh Heru Sutojo, Salemba Empat: Jakarta.

Huang, Y., Tsai, C.H and, Chen, C.C. 2007, Expected $\mathrm{P} / \mathrm{E}$, residual $\mathrm{P} / \mathrm{E}$ and Stock Return Reversal: Time-Varying Fundamentals of Investor Overreactions?, International of Journal of Business and Economics, 2007, Vol 6 No. 1, page 11-28.

Husnan, S., 2003. Dasar-dasar Teori Portofolio dan Analisis Sekuritas. Edisi Keempat, Yogyakarta : UPP AMP YKPN.

Jogiyanto, 2003. Teori Portofolio dan Analisis Investasi. Edisi Tiga. BPFE, Yogyakarta.

Jones, C. P, 2007. Investment, Analysis and Maangement, John Wiley \& Son Inc.

Kusuma,H.,Handojo,2004, KandunganInformasi Tambahan dari Laba, Modal Kerja Operasi, Arus Kas pada Perusahaan Manufaktur Go Public Tahun 1997-2001, Jurnal Kajian Bisnis Dan Manajemen, Sinergi Vol 7 No. 1 Tahun 2004, Hal 1-12, issn : 1410-9018.

Li, J. L., Zhang,L. dan Zhou, Z., 2005. Earnings Management and Delisting Risk: The Case of IPO Firms, Available, http://www.ssrn.com.

Sasongko, N., Wulandari, N. 2006. Pengaruh EVA dan Rasio-rasio Profitabilitas Terhadap Saham. Empirika, Vol. 19 No. 1, Juni 2006 64-80.

Sawir, A., 2005, Analisis Kinerja Keuangan dan Perencanaan Keuangan Perusahaan, Penerbit PT. Gramedia Pustaka Utama, Jakarta.

Setyaningrum, A., Hartono, Y., 2000. Abnormal Return dengan Strategi Analisis Fundamental, Sosiohumanika, Pasca Sarjana Universitas Gajah Mada, halaman 275-289.

Sivaprasad, Muradoglu, 2010. Corresponding Aothor, Cass Business Scholl, 106 Bunhil 
Row. London, ECIY 8TZ, United Kingdom, Muradoglu@city,ac.uk.

Sugiyono, (2003), Metode Penelitian Bisnis, Edisi revisi kedelapan, Bandung, CV Alfabeta.

Suharli, M., 2005. Studi Empiris Terhadap Dua Faktor yang Mempengaruhi Return Saham pada Industri Food \& Beverages di Bursa Efek Jakarta. Jurnal Akuntansi Indonesia Vol 7 Nol2, November 2005, 99-116.

Sunarto, 2001. Pengaruh Rasio Profitabilitas dan leverage terhada return saham perusahaan manufaktur di BEJ, Jurnal Bisnis dan Ekonomi, Stie Stikubank Semarang, Maret 2001.

Tadellilin, E., 2010, Analisis Investasi dan Manajemen Portofolio, Edisi Revisi, Badan Penerbit Fakultas Ekonomi Universitas Gajah Mada, Yogyakarta.

Trevino, Robertson, 2002, P/E Ratio and Stock Market Returns, FPA Journal, Past Issues \& Articles, International Research Journal of Finance an Economics C.EuroJournal Publising,Inc, http//ssrn.com/abstract 597922.

Ullupui, I.G.K.A., 2009. Analisis Pengaruh Rasio Likuiditas, Leverage, Aktivitas dan Profitabilitas Terhadap Return Saham : Studi Perusahaan Makanan dan Minuman dengan Kateori Industri Barang Konsumsi di BEJ, Jurnal, Universitas Udayana, Bali

Wahyuni, S., 2002, Analisis Kandungan Informasi Laporan Arus Kas di Bursa Efek Jakarta, Jurnal Ekonomi dan Bisnis Indonesia, Vol. 17 No. 2, 2002, hal 200-210.

Weston, J. F. dan Brigham, E.F., (1998), Dasar-dasar Manajemen Keuangan, edisi kesembilan, Jilid 1. Edisi Ketujuh, Cetakan Kelima, terjemahan A.Q. Khalid, Penerbit Erlangga, Jakarta.

Wild, J. J., Subramanyam, K. R., and Halsey, Robert F., (2005). Financial Statement Analysis, Analisis Laporan Keuangan, Edisi 9, Terjemahan Yanivi S. Bachtiar dan S.Nurwahyu Harahap, Salemba Empat, Jakarta. 